\title{
How much energy to process one pound of meat? A comparison of energy use and specific energy consumption in the meat industry of four European countries
}

\author{
C.A. Ramírez*, M. Patel, K. Blok \\ Department of Science, Technology and Society, Copernicus Institute, Utrecht University, \\ Heidelberglaan 2, 3584 CS, Utrecht, The Netherlands
}

Received 6 October 2004

\begin{abstract}
In this paper, we have used energy and physical production data to develop energy efficiency indicators for the meat industry of four European countries for the last 15 years. Our results show a significant increase in the energy use per tonne of product in all countries (between 14\% and 48\%). In order to understand the drivers behind the trends, factors such as the share of frozen products, the share of cut-up products and increasing food hygiene measures are analysed. We find that strong hygiene regulations can explain between one and two-thirds of the increase while the role of increasing shares of frozen and cut fresh meat it is found to be of no significance.
\end{abstract}

(C) 2005 Elsevier Ltd. All rights reserved.

Keywords: Energy efficiency; Meat sector; Specific energy consumption

\section{Introduction}

The increasing importance of energy efficiency has been highlighted by the Intergovernmental Panel on Climate Change (IPCC) in its last report when stating that "almost all greenhouse mitigation and concentration stabilization scenarios are characterized by the introduction of energy efficient technologies for both energy use and supply" and that "improvement of energy efficiency of industrial processes is the most significant option for lowering greenhouse gas emissions" [1, p. 8; 38]. However, developing and implementing policies that effectively promote energy efficiency require a thorough understanding of the economic, technical and behavioural drivers underlying energy consumption trends. Until recently most in-depth energy analyses for the manufacturing sector focussed on energy intensive branches (e.g., steel, cement, aluminium) while disregarding non-energy intensive sectors (e.g., food, textiles, machinery). There are three main reasons for this. Firstly, significant reductions in energy consumption (and $\mathrm{CO}_{2}$ emissions) can be achieved by focussing on a few energy intensive sectors. Secondly, also due to their high-energy consumption, detailed information

*Corresponding author. Tel.: + 31302537639; fax: + 31302537601.

E-mail address: c.a.ramirez@chem.uu.nl (C.A. Ramírez). 
on energy use is available. Finally, we found that for those energy intensive sectors on which in-depth energy analyses have been performed, the diversity of key products, technologies and processes tend to be fairly limited, which implies that meaningful analyses can be prepared without going into too much detail. On the contrary, a key feature of non-energy intensive sectors is their heterogeneity. It is therefore not a straightforward task to identify from an extensive list of products, processes and technologies, the ones that have enough explanatory power with regard to energy efficiency; and even when this is clear, there is often a lack of reliable data which would be required to develop consistent time series and cross-country comparisons.

A related important issue is the choice of the indicator used when monitoring energy efficiency developments in the manufacturing sector. The use of energy per unit of output is the most common indicator for assessing trends and developments in energy efficiency. Given the large variety of products in the nonenergy intensive sectors the simplest and, therefore, preferred approach when analysing non-energy intensive sectors is to use economic values as the measure of output (i.e., energy per unit of production value or value added). It is, however, questionable whether economic-based energy efficiency indicators (EEIs) are a good measure for changes in technical energy efficiency [2,3]. Therefore, EEIs based on physical amounts of output (i.e., energy per tonne) are often mentioned as the most reliable indicators to provide estimates of changes in energy efficiency (see Refs. [2,4-7]).

Against this background, and taking into account new developments such as the European Union (EU) draft Directive on energy end-use efficiency and energy services, which has as one of its main target groups non-energy intensive sectors [8], the main focus of this paper is to conduct a comparative assessment of EEIs in a selected non-energy intensive sector: the meat sector. The meat sector (NACE 151) ${ }^{1}$ comprises the production and preservation of beef, sheep, goat and pork meat (NACE 1511), poultry meat (NACE 1512) plus the further processing of all types of meat, e.g., the production of sausages or ham and intermediate products like plasma and animal fat (NACE 1513). Production here refers to slaughtering, rendering and meat processing and storage (Fig. 1), while husbandry and retail activities are not included.

The goal of this paper is two-fold. Firstly, we want to examine patterns of production and energy use in the meat sector of four European countries: France, Germany, the Netherlands and the United Kingdom. Secondly, we examine whether it is feasible to develop physical-based EEIs and we examine their strength.

\section{Data}

One of the critical points, as well as the most time consuming, when constructing indicators is data gathering. This section provides an overview of the data sources used in this paper. The time period covered in this study was determined by the availability of consistent and disaggregated energy data. Hence, for the Netherlands and France [9,10] the analysis covers the period 1986-2001 while it is restricted to 1990-2001 for the United Kingdom [11] and 1993-2001 for Germany [12]. Data for earlier years would have been available for Germany but have been proven to be unreliable and inconsistent due to different reporting systems and economic systems prior to reunification.

Unless indicated otherwise, energy data in this paper refer to primary energy. To this end, the contribution of electricity to primary energy demand has been calculated by multiplying the electricity end use by 2.5 (corresponding to a $40 \%$ electricity generation efficiency). ${ }^{2}$ In this paper, we work with net final energy data, hence, the electricity values used correspond to the electricity bought from the grid minus the electricity sold by the industry. Energy data reported by France and the Netherlands represent net calorific values (NCV), while the British and German data are based on gross calorific values (GCV). ${ }^{3}$ We have adjusted the British and German energy data to a NCV basis by using the net/gross ratios that are also applied by the IPCC [13] and the International Energy Agency [14]: 0.95 for coal and oil and 0.9 for natural gas. We have also corrected

\footnotetext{
${ }^{1} \mathrm{NACE}$ is the classification of economic activities in the European community (EC). Statistical data is generally reported according to this classification.

${ }^{2}$ We maintain the electricity generation efficiency constant in order to determine purely the effect of efficiency improvement on the energy demand side; otherwise effects of efficiency improvements in power generation (energy supply side) would also be included.

${ }^{3}$ The difference between NCV and GCV is the latent heat of vapourization of the water produced during the combustion of the fuel. NCV excludes this heat.
} 


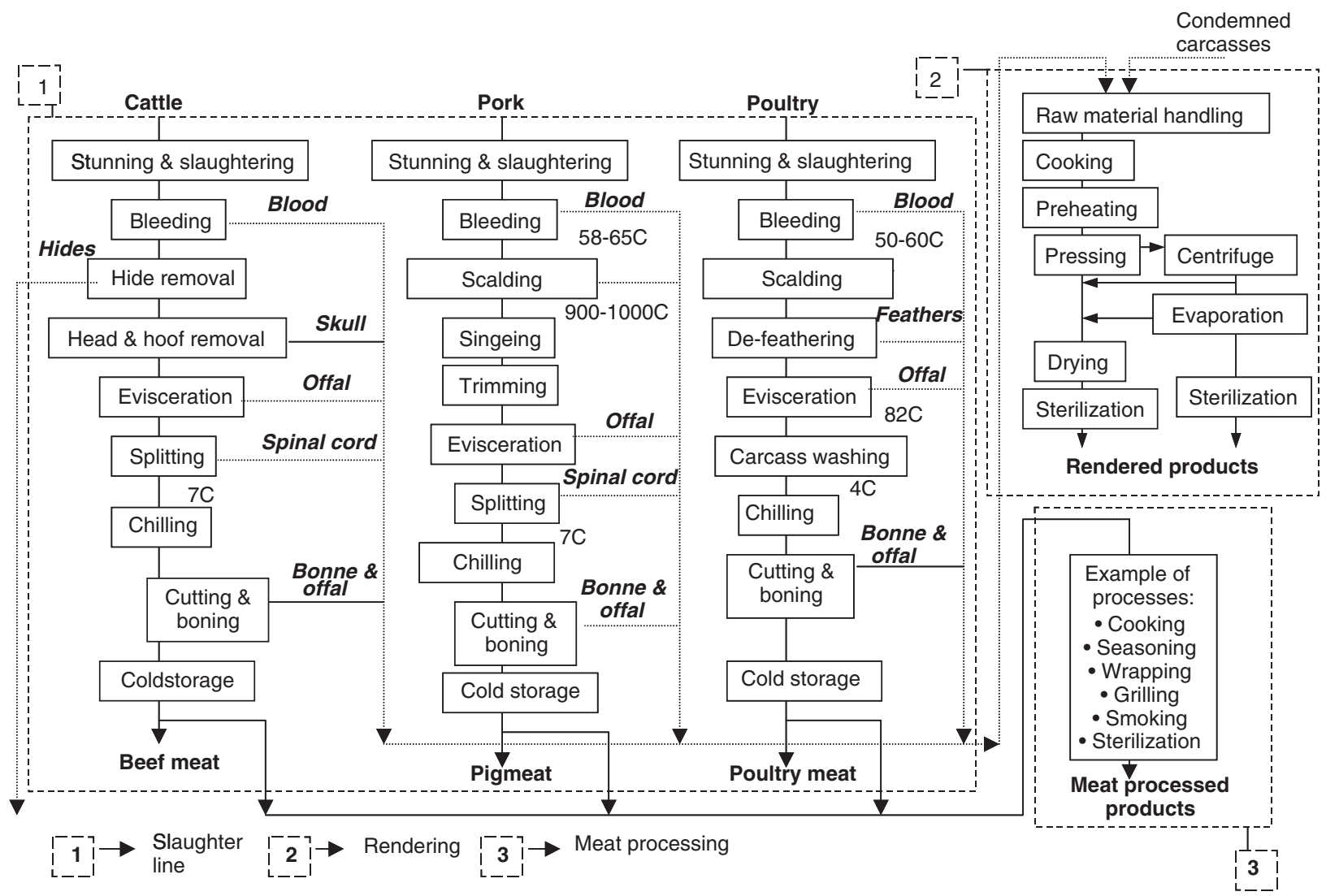

Fig. 1. Process flow diagram of the meat sector.

the energy figures for climate influences using the Eurostat temperature correction method ${ }^{4}$ (assuming a heating share of $20 \%$ based on data published in [16,17]).

Time series for physical production data were developed using data provided by national statistical offices and by industrial associations. Amounts of slaughtered meat were calculated from information on slaughterings and average dress carcass weights. Amounts of further processed meat products were taken from national Prodcom statistics, ${ }^{5}$ which are based on industrial sales figures. Additionally, international databases were used for closing data gaps and for crosschecks [18,19].

\section{Production developments in the meat sector}

Meat production in the countries studied has increased between $5 \%$ and $13 \%$ in the last decade. The production structure, however, has changed substantially, with a shift away from red meats towards white meats (especially poultry) and processed meat products (Fig. 2). The declining trend in beef production has several causes. First of all, the decreasing status of meat and its declining nutritional significance together with the damage of public confidence in beef due to food scandals ${ }^{6}$ have accelerated existing trends towards what is perceived as a healthier meat: poultry [20-22]. Another cause of the decline is a side effect of the milk quota

\footnotetext{
${ }^{4}$ The temperature correction method of Eurostat is based on the share of fuels used for heating purposes. Hence the temperature corrected energy $\left(E_{\mathrm{nt}}\right)$ is given by given by $E_{\mathrm{nt}}=E_{\mathrm{ht}} / d_{\mathrm{t}}+E_{\mathrm{pt}}$, where $E_{\mathrm{ht}}$ is the energy used for heating purposes, $E_{\mathrm{pt}}$ is the energy used for non-heating purposes, and $d_{\mathrm{t}}=D_{\mathrm{t}} / D$, where $D_{\mathrm{t}}$ and $D$ are the actual and long-term degree days, respectively [15].

${ }^{5}$ PRODCOM is the European Community's classification for production statistics.

${ }^{6}$ For instance, Escherichia coli in beef trimmings, the use of hormones in cattle, the Bovine Spongiform Encephalopathy (BSE) crisis in the United Kingdom, the Creutzfeld-Jakob disease $(v C j d)$ and the mouth and foot disease.
} 

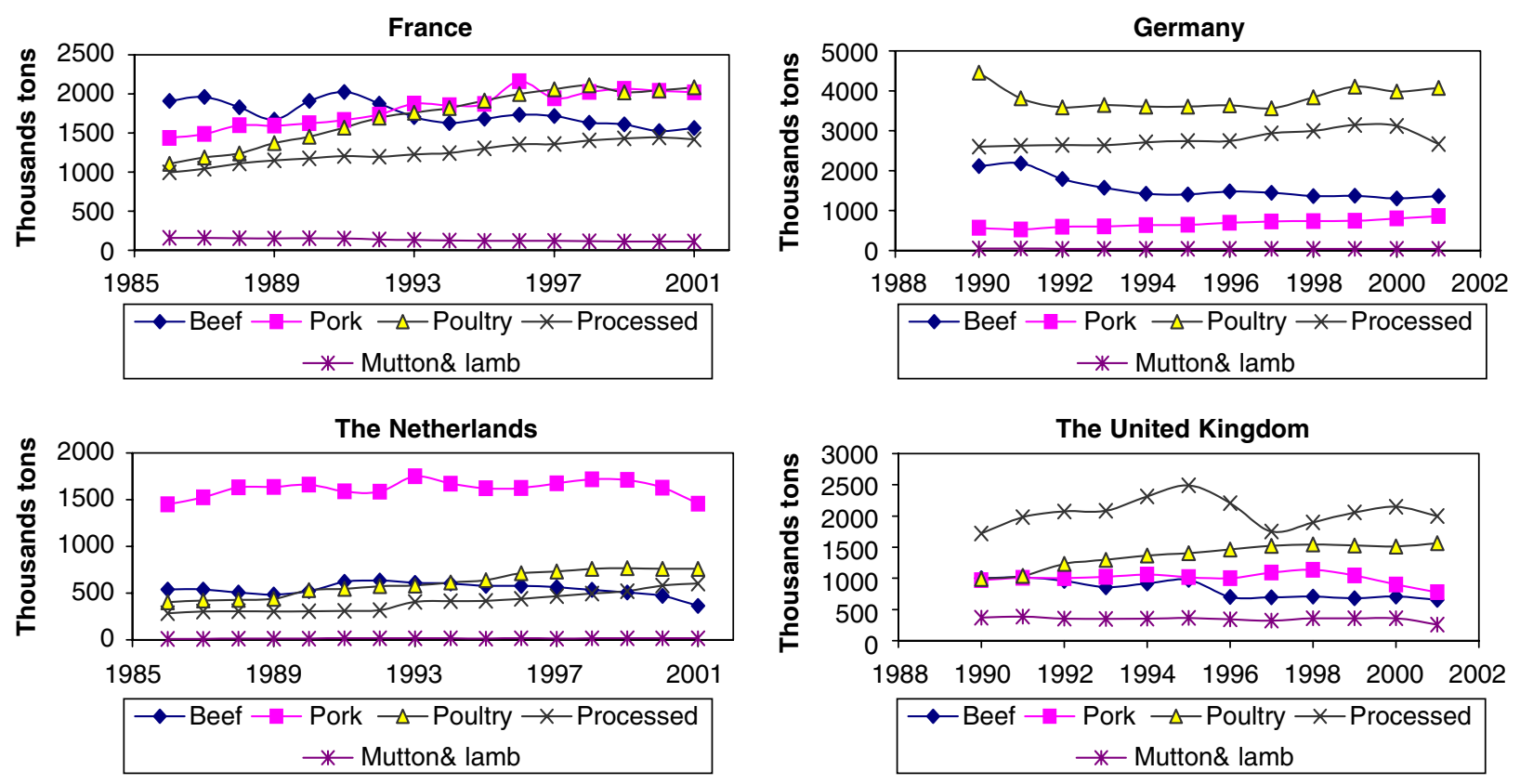

Fig. 2. Trends in meat production by country.

system established by the EU. Since beef production is based for the greater part on the dairy industry, ${ }^{7}$ the decrease in cattle and increase of milk efficiency per cow, which allows farmers to fill their milk quota with fewer cows, has resulted in less available cattle for slaughter.

Contrary to the developments observed for beef production, and despite the food scandals, poultry and pork production have increased in the last decade. Nevertheless, the growth rate of pork production has fallen behind the increase shown by the poultry sector. In the Netherlands, for instance, two main reasons can be identified: (a) low producer prices (for poultry) and, (b) the new legislation for animal husbandry (environmental measures) which has mainly consequences for pork production. These measures (e.g., restrictions on the number of pigs held per farm) are an attempt of the Dutch government to respond to public concerns for animal welfare, intensive livestock farming and the current manure surplus problem and have led to the reduction of the pig stock. Furthermore, outbreaks of swine vesicular disease in 1994 and 1997 further diminished the Dutch pig stocks.

Poultry production, on the other hand, has in fact benefited from the red-meat crisis. As noted above, people perceive poultry as healthier than beef or pork: poultry meat is considered by consumers as being lighter and having a lower fat content. Besides, the increase in poultry is in part due to the fact that poultry production allows to respond to changes in the sector more promptly than other types of meat. Compared to other sectors, the poultry sector of the EC is facing a very liberal market organization, where there are no guaranteed prices or intervention systems [22]. Another factor, which has favoured the increase of poultry production, is the evolution in consumer prices. Compared with other meats, poultry is an inexpensive meat which has remained cheaper resulting in an increased market share at the expense of other types of meat, particularly beef [25]. In addition to the factors just outlined, the increase in poultry production can also be related to animal efficiency. It has been reported that in Europe, to produce $1 \mathrm{~kg}$ of broiler meat, it takes $3.1 \mathrm{~kg}$ of dry matter feed, whereas pigs require $6.2 \mathrm{~kg}$ of feed and non-dairy cattle $24 \mathrm{~kg}$ of feed [26]. These ratios make poultry an attractive option for farmers.

Fig. 2 also shows an increasing trend in the production of processed meat products. This increase has been driven by efforts to add value and improve margins and in response to end-user demand. At a first sight, and

\footnotetext{
${ }^{7}$ In $1995,43 \%$ of Dutch beef and veal production came from culled dairy cows [23], in the United Kingdom the percentage was about $60 \%: 41 \%$ from the dairy herd and $22 \%$ from culled cows [24].
} 


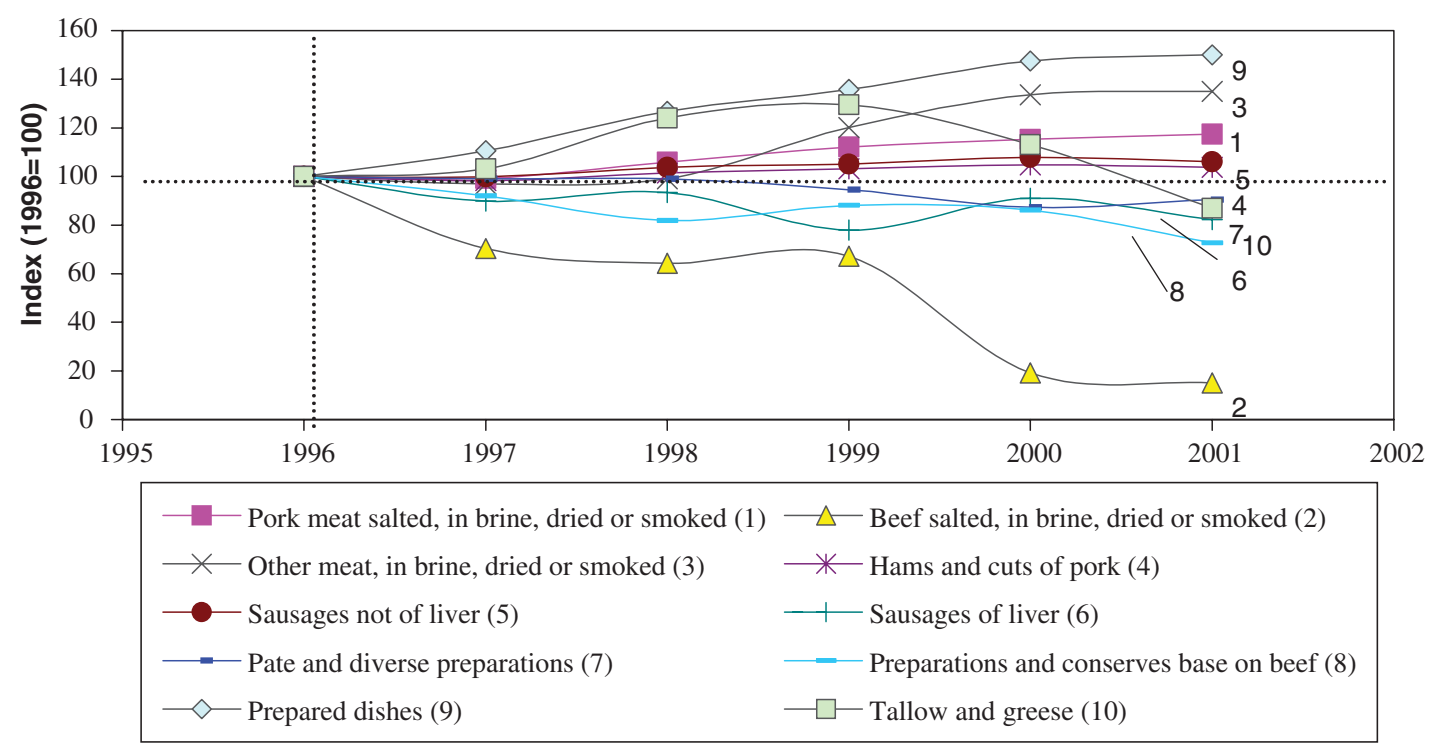

Fig. 3. Physical production of meat products in France (Indexed to 1996).

Table 1

Number of slaughterhouses by kind of animal and country

\begin{tabular}{|c|c|c|c|c|c|c|c|c|}
\hline \multirow[t]{2}{*}{ Animal type } & \multicolumn{2}{|c|}{ France $^{\mathrm{a}}$} & \multicolumn{2}{|c|}{ Germany $^{\mathrm{b}}$} & \multicolumn{2}{|c|}{ United Kingdom $^{\mathrm{b}}$} & \multicolumn{2}{|c|}{ Netherlands ${ }^{\mathrm{c}}$} \\
\hline & 1988 & 2001 & 1990 & 1997 & 1987 & 1997 & 1985 & 1996 \\
\hline Cattle & 580 & 343 & 178 & 210 & 835 & 395 & $331^{\mathrm{d}}$ & 267 \\
\hline Pigs & & & 221 & 210 & 703 & 308 & 55 & 25 \\
\hline Poultry & 1392 & 186 & 157 & 115 & $\mathrm{n} . \mathrm{a}$ & n.a & 91 & 52 \\
\hline
\end{tabular}

${ }^{\mathrm{a}}$ Data provided by Agreste [10].

${ }^{\mathrm{b}}$ Northen et al. [27].

${ }^{\mathrm{c}}$ Langeveld, 2000.

${ }^{\mathrm{d}}$ Data for 1991.

with the exception of the United Kingdom, the crisis in the meat sector in the mid 1990s does not seem to have affected the further processing of meat products substantially. However, an analysis of production trends for France indicates that production of processed products based on beef have declined while those based on poultry or pork have increased (Fig. 3). Hence, it seems that developments found for slaughtering activities (especially cattle) can be found back in the processed meat sector, albeit to a lesser extent.

Other interesting developments in the meat sector are the shift from slaughtering by many small facilities to a handful of large facilities which control the market $^{8}$ (Table 1), and the increase in the size of the largest facilities (e.g., it is reported for the United Kingdom that in 1992/3 abattoirs numbers were $40 \%$ of those operating in 1972/3, but the average slaughterhouse had a throughput that was 2.5 times higher than 20 years before [27]). Industry concentration in the meat sector could be explained by the need to comply with higher environmental and health standards. This has prompted companies to undertake new investments. A study made by the Organization for Economic Cooperation and Development (OECD) pointed out that the implementation cost of the EU[36] hygiene standards (Directive 91/497/EEC) in the United Kingdom was potentially high and hence the burden on small operators was likely to be particularly great since it is difficult

\footnotetext{
${ }^{8}$ In the United Kingdom 30 pig abattoirs accounted in 1997 for $81.4 \%$ of throughput, while 15 cattle abattoirs accounted for $40 \%$ of throughput; in Germany, 27 poultry slaughterhouses accounted for about $92 \%$ of total throughput.
} 

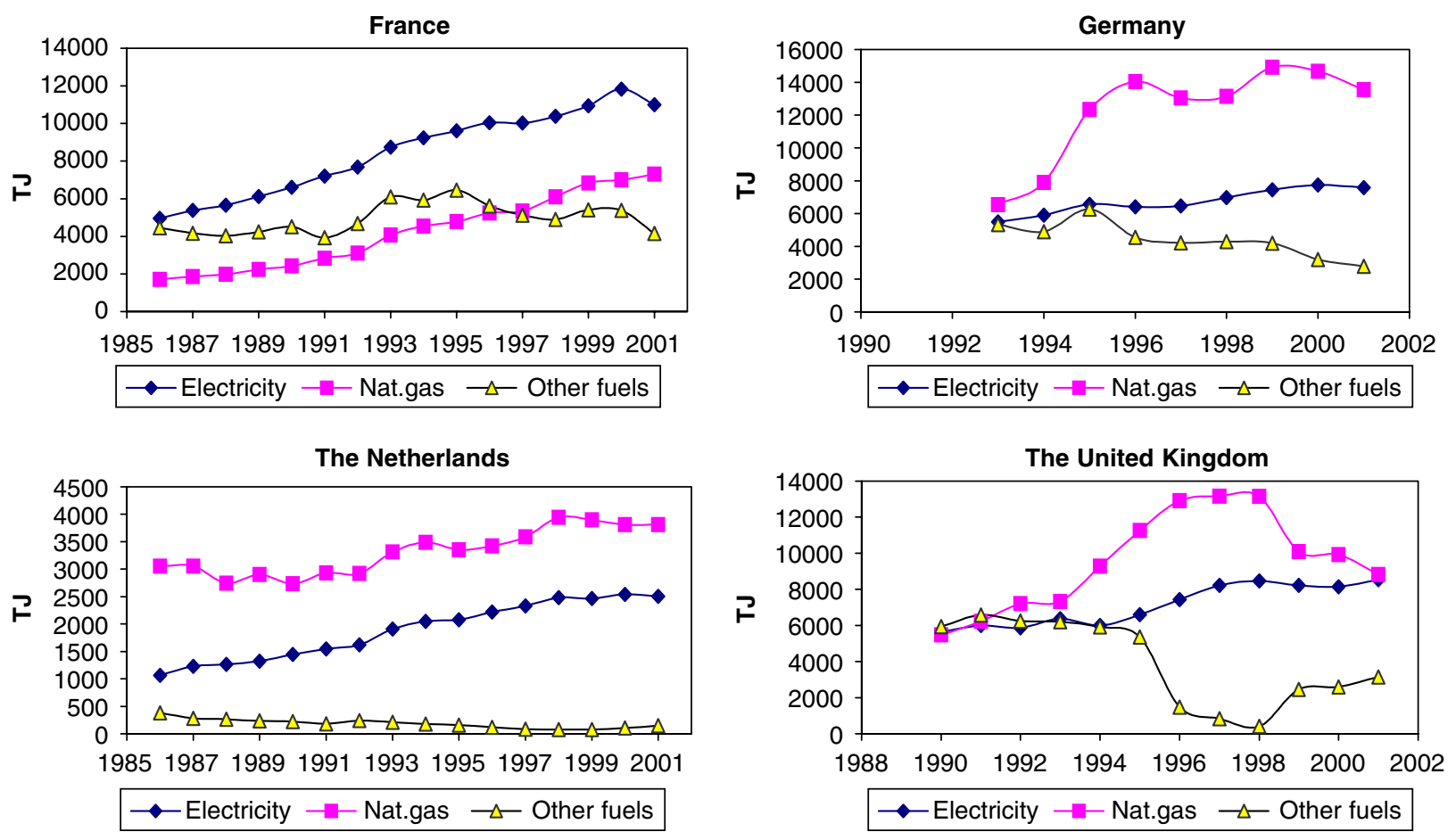

Fig. 4. Developments in final energy consumption by fuel and country in the meat industry.

for small plants to generate sufficient turnover to absorb the costs of upgrading to meet the standards [28]. Furthermore, there are significant economies of scale associated with the cost of upgrading plants. Consequently, the Directive has most likely supported the process of concentration.

\section{Energy use}

In the year 2001, the meat sector consumed about 39, 35, 10 and $32 \mathrm{PJ}$ of primary energy in France, Germany, the Netherlands and the United Kingdom, respectively. Of this amount, between $40 \%$ and $60 \%$ was used by the further processing of meat sector (NACE 1513). Fig. 4 shows the increasing trend in energy consumption by the whole meat sector. Natural gas is the fuel used most in the Netherlands, Germany and the United Kingdom, while in France it is electricity. One important reason for the high share of electricity in the French meat industry is the efforts promoted by the French government to use electricity for process heat, a trend not existing in the other countries [29,30].

There has been a trend in all countries towards higher electricity use due to increasing demands for refrigeration and motor drive power. Table 2 shows the annual growth of both final and primary energy consumptions. The effect of electricity growth in terms of primary energy is substantial.

Table 3 shows the distribution of final energy in the meat sector by energy function, subsector and fuel. ${ }^{9}$ Fossil fuels are mainly used for process heat while the main use of electricity is cooling. Refrigeration constitutes between $45 \%$ and $90 \%$ of total final electricity use during working day and almost $100 \%$ during non-production periods [16].

\section{Understanding energy efficiency developments}

In this section, we study the developments in energy efficiency made in the meat industry by examining the use of energy per unit of physical output (hereafter referred to as specific energy consumption). In general,

\footnotetext{
${ }^{9}$ Note that not all activities are reported, hence values do not necessarily add to $100 \%$.
} 
Table 2

Increase of annual total final and primary energy in the meat sector by country

\begin{tabular}{llll}
\hline Country & Growth of total final energy consumption (TFC) (\% p.a.) & $\begin{array}{l}\text { Growth of primary energy } \\
(\text { PE) (\% p.a.) }\end{array}$ \\
\cline { 2 - 4 } & Fuels & Electricity & 4.6 \\
\hline France $^{\mathrm{a}}$ & 3.8 & 5.0 & 6.3 \\
Germany $^{\mathrm{b}}$ & 3.4 & 3.6 & 3.2 \\
The Netherlands $^{\mathrm{a}}$ & 0.9 & 5.3 & 2.9 \\
United Kingdom $^{\mathrm{c}}$ & 0.4 & 3.7 & \\
\hline
\end{tabular}

a $1986-2001$.

${ }^{\mathrm{b}} 1993-2001$.

${ }^{\mathrm{c}} 1990-2001$.

Table 3

Energy consumption in the meat industry

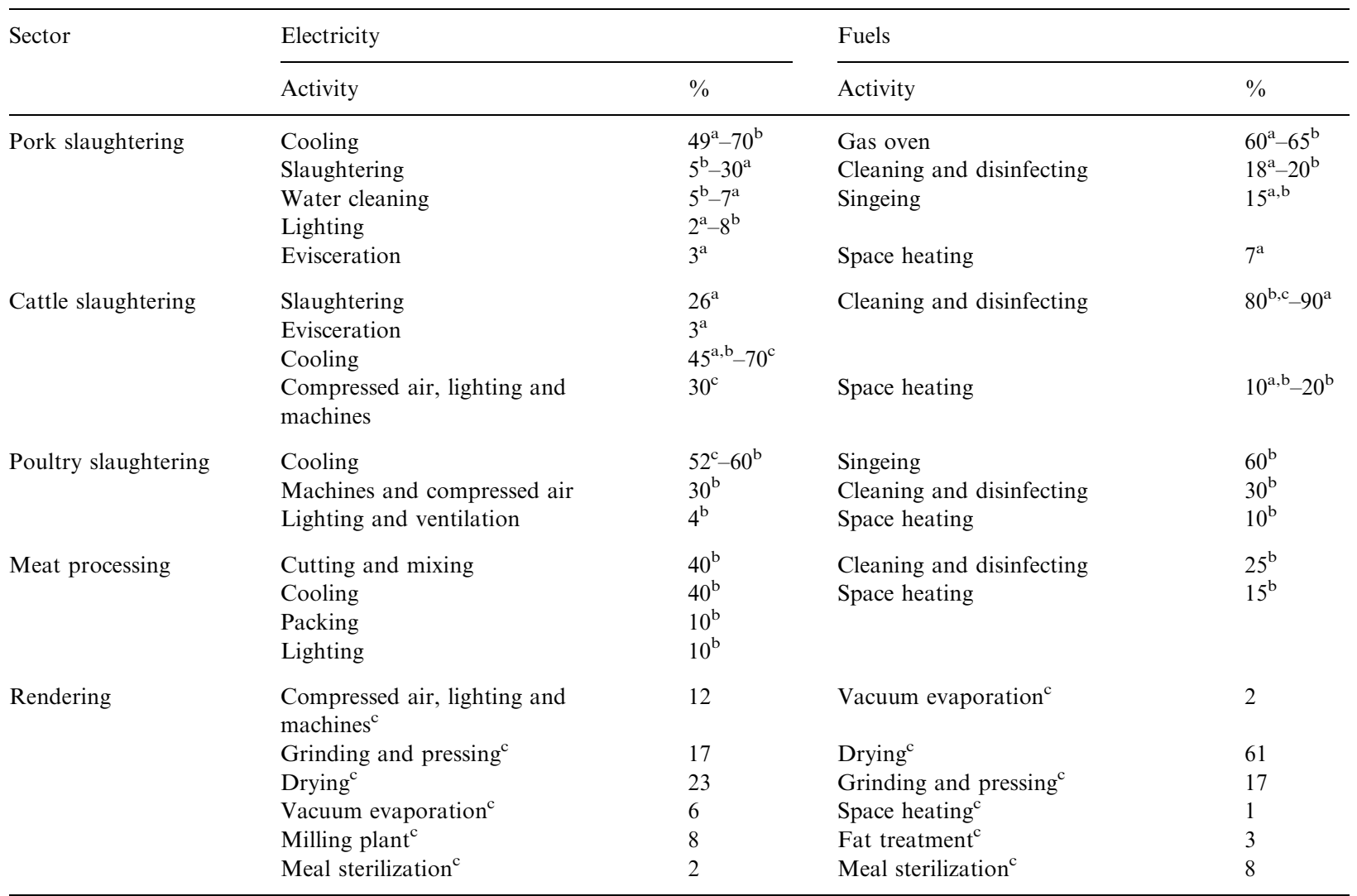

${ }^{\mathrm{a}}$ Pontoppidan and Hansen [33].

${ }^{\mathrm{b}}$ Infomil [17].

${ }^{\mathrm{c}} \mathrm{EC}[16]$.

Eq. (1) can be used to calculate the specific energy consumption.

$$
\mathrm{SEC}_{i}=\frac{E_{i}}{m_{i}}
$$

where $\mathrm{SEC}_{i}$ is the specific energy consumption for product $i$ (e.g., $\mathrm{MJ} / \mathrm{t}$ ); $E_{i}$ the primary energy consumption of product $i$ (e.g., in $\mathrm{MJ}) ; m_{i}$ the physical production of product $i$ (e.g., in tonnes of dress carcass weight). 
When more than one product is manufactured, Eq. (1) needs to be modified. If products differ significantly in terms of energy requirements, changes in the results provided by Eq. (1) would be partly due to changes in efficiency and partly due to changes in production mix. Following the methodology developed by Phylipsen et al. [7] and Farla and Blok [31], we correct Eq. (1) for differences in product mix. This is done by comparing the realized energy use (published by statistical offices) with a scenario where there is no improvements in energy efficiency (hereafter referred to as a frozen energy efficiency). We call this an EEI (Eq. (2)). ${ }^{10}$ The frozen efficiency scenario is developed by taking into account the differences in energy requirements between products by using the specific energy consumption of the products $\left(\mathrm{SEC}_{\mathrm{ref}}\right)$ in a base year. In this paper, we use $\mathrm{SEC}_{\mathrm{ref}}$ values which reflect typical technologies in use in the late 1990s.

$$
\mathrm{EEI}_{j}=\frac{\text { Realised energy use }}{\text { Frozen efficiency }} \cong \frac{\sum_{i} E_{i, j}}{\sum_{i} m_{i, j} \times \mathrm{SEC}_{\mathrm{ref}_{i, j}}}=\frac{E_{j}}{\sum_{i} m_{i, j} \times \mathrm{SEC}_{\mathrm{ref}_{i, j}}},
$$

where $\mathrm{EEI}_{j}$ is the EEI of sector $j$ (dimensionless); $E_{i, j}$ the primary energy consumption of product $i$ in sector $j$; $E_{j}$ the primary energy consumption of sector $j$ as given in the statistics (e.g., in MJ); $m_{i, j}$ the physical production of product $i$ in sector $j$ (e.g., in tonnes of dress carcass weight); and $\mathrm{SEC}_{\mathrm{ref}, i}$ the reference value for the specific energy consumption of product $i$ (e.g., in $\mathrm{MJ} / \mathrm{t}$ ).

We identified: beef/veal meat, goat meat, sheep and lamb meat, poultry meat, pig meat, rendered products and processed products as key products. ${ }^{11}$ We use for the cattle, pig and poultry processing $\mathrm{SEC}_{\text {ref }}$ values reported in two studies [32,33] and for the further processed meat industry, values reported by Suijkerbuijk et al. [34] (despite efforts made for gathering information on $\mathrm{SEC}_{\mathrm{ref}}$ for processed meat products, only aggregate figures were obtained). The meat sector also includes the processing of meat by-products (i.e., bones, blood, feathers, fat). Since some of the by-products submitted to rendering process are not processed for sale (i.e., fallen stock or offals that are considered a danger to public health), it is important to work with the annual amount of raw material to be rendered and not with production data based on sales figures (this underestimates the influence of rendering in the energy consumption of the sector). As there is a lack of statistical data on the total annual amount of raw material to be rendered, we make the following assumptions. Firstly, we assume that the total weight of raw material to be rendered per beast is typically ${ }^{12}$ $198 \mathrm{~kg}$ (cattle), $21 \mathrm{~kg}$ (pig), $14 \mathrm{~kg}$ (sheep) and $0.7 \mathrm{~kg}$ (poultry) [35]. Secondly, contrary to the United Kingdom, in Germany, France and the Netherlands it is forbidden to bury fallen stock on farm, these amounts are included in our calculations. Hence, it is assumed that fallen stock represents $10 \%$ (for the Netherlands) and $15 \%$ (for Germany and France) of the tonnage processed annually. ${ }^{13}$ Finally, we assume that rendering is done in a continuous system with cooking and multiple-effect evaporation in added fat. ${ }^{14}$ The $\mathrm{SEC}_{\mathrm{ref}}$ used is based on data provided by Nielsen [37] and Schreurs [38]. Table 4 shows an overview of the $\mathrm{SEC}_{\text {ref }}$ used in this paper.

The results of applying Eq. (2) to the meat sector (NACE 151) are shown in Fig. 5. The results point towards an increasing primary energy consumption per unit of output during the last decade $(32 \%$ in France, ${ }^{15} 27 \%$ in Germany, ${ }^{16} 14 \%$ in the United Kingdom and $27 \%$ in the Netherlands for the period

\footnotetext{
${ }^{10}$ In principle, the method used to develop the energy efficiency indicator EEI is similar to factor decomposition methods, which are generally used in the analysis of economic energy intensity. In both cases, changes in energy efficiency are analysed by correcting the energy intensity for changes in structure. The difference between the two methods can be explained as follows. In the case of factor decomposition methods, structure is defined by expressing the activities of the sector in economic terms (e.g., value added). The corrected indicator can be interpreted as a proxy of changes in physical energy efficiency. Factor decomposition uses activity data from economic statistics, which are then decomposed; it therefore represents a top-down approach. In the EEI, we correct for structure by directly using data representing the changes in the physical production of the sector (see Eq. (2)). The EEI is, hence, the result of a bottom-up approach where the energy consumption of a sector is recalculated based on individual processes.

${ }^{11}$ Within the processed products, we include the following products: Ham; bellies and cuts of swine salted, in brine, dried or smoked; pig meat salted, in brine, dried or smoked (including bacon); sausages; prepared pork meat (including mixtures); preparations of beef and veal.

${ }^{12}$ These amounts exclude treatment of hides and skins because this is generally done in tanneries.

${ }^{13}$ Based on survey data published by MLC [36].

${ }^{14}$ In this kind of process, the material is minced, heated, pressed and separated in a twin screw press, thereafter the fat is separately sterilized. The wet protein fraction is then dried and sterilized without fat present [36]. This process provides a high-quality fat and meat and bone meal low in fat content, of an upgraded quality, of a light colour and highly digestible.

${ }^{15}$ The increase in the EEI for the period 1986-2001 was of $48 \%$ in France and $25 \%$ in the Netherlands.

${ }^{16}$ In the period 1993-2001.
} 
Table 4

Specific energy consumption values in the meat industry (in primary energy, typical technologies for the late 1990s)

\begin{tabular}{lll}
\hline Product & Unit & SEC $_{\text {ref }}$ \\
\hline Beef, veal and sheep & $\mathrm{MJ} / \mathrm{t}$ dress carcass weight & 1390 \\
Poultry & $\mathrm{MJ} / \mathrm{t}$ dress carcass weight & 3096 \\
Pork & $\mathrm{MJ} / \mathrm{t}$ dress carcass weight & 2097 \\
Meat products & $\mathrm{MJ} / \mathrm{t}$ final product & 5500 \\
Rendering & $\mathrm{MJ} / \mathrm{t}$ of raw material processed & 1625 \\
\hline
\end{tabular}

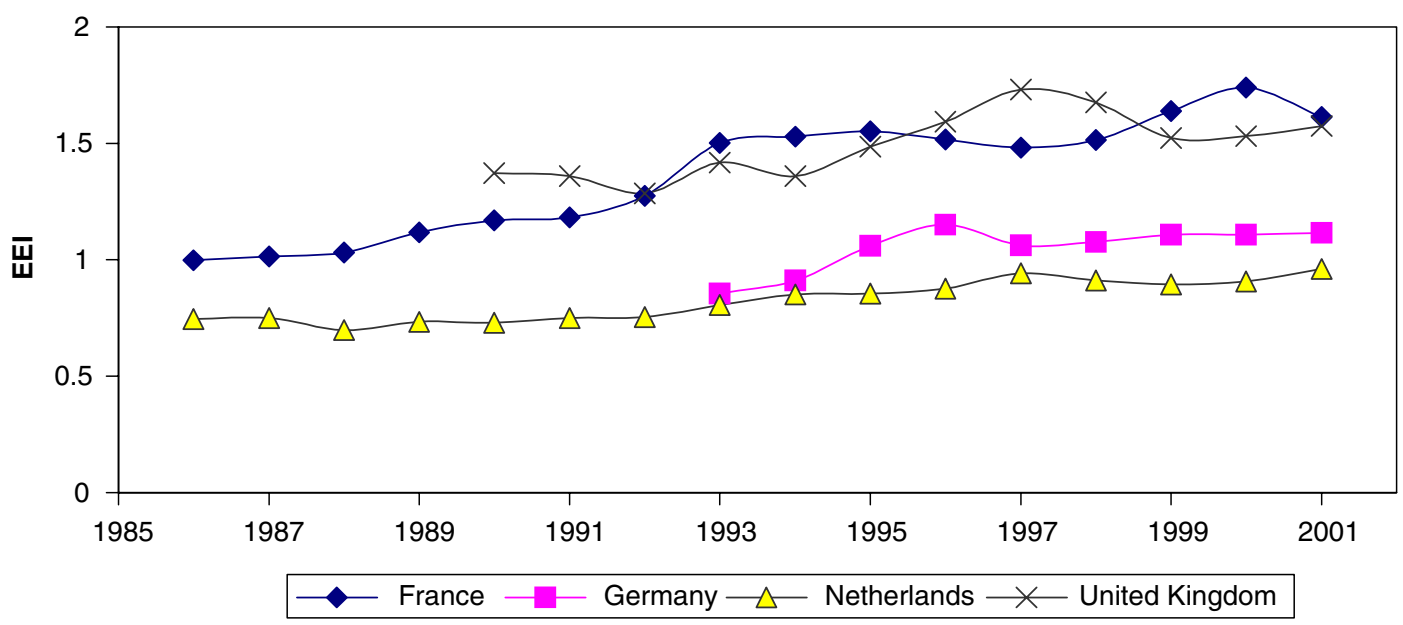

Fig. 5. Energy efficiency indicators of the meat industry by country.

1990-2001). The general increase in EEI by the meat industry is troublesome since one could expect that even in the absence of energy saving policies, there would be autonomous energy-efficient developments. In the next section we explore some factors that could explain the general deterioration in energy efficiency for the meat sector.

\section{Discussion of results}

The increasing energy demanded by the meat sector can be explained by two main factors. On the one hand, increasing demand is caused by the change in consumer preferences from beef towards pigmeat and poultry (see Section 4) since poultry and pork slaughtering are more energy intensive than cattle slaughtering ${ }^{17}$ (see Table 4). On the other hand, the meat industry has progressed from the sales of carcasses, complete with fat and bone, to large bone-in or boneless cuts that are vacuum packaged, fully trimmed products and pre-cooked and ready-to-eat products which increases the demand in electricity and fuel. At this point, it is worth pointing out that the second factor could lead to a compensating decrease in energy consumption in the commercial and residential sector. The analysis of this effect falls, however, outside the scope of the present paper and warrants further research. In order to understand the deterioration in energy efficiency we explore two main trends in the meat industry and their influence on the EEI: (a) shifts in meat products and (b) the increasing demand for food security.

\footnotetext{
${ }^{17}$ This is due mainly to the energy consumed in dehairing, defeathering and singeing operations as illustrated in Fig. 1.
} 


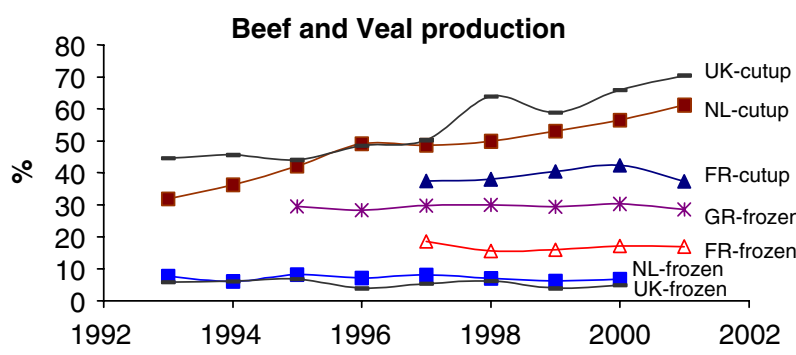

(A)

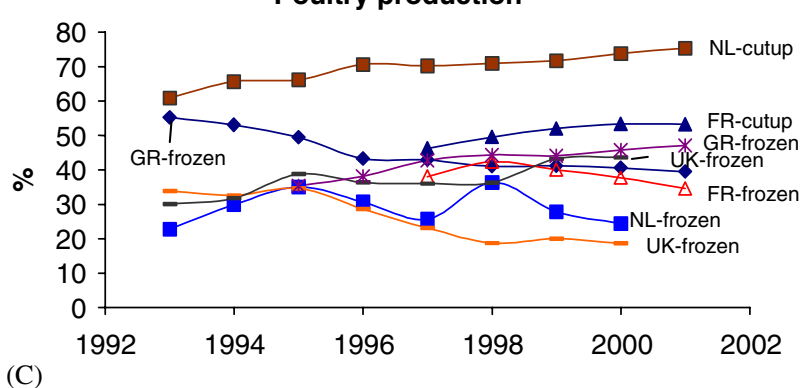

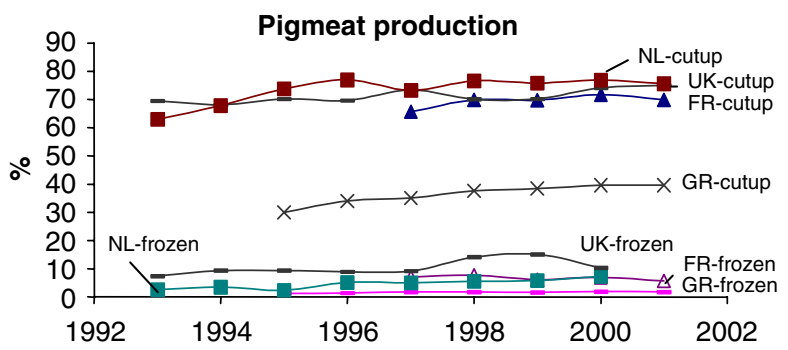

(B)

NL: Netherlands

FR: France

GR: Germany

UK: United Kingdom

Fig. 6. Share of frozen products and cut-up products in meat production by product and country.

\subsection{Structural changes: increasing demand of fast food, cut and frozen products}

In a sector such as the meat industry, growth is heavily influenced by changing consumer preferences. In order to understand changes in production mix that have not yet been captured by our indicator, we differentiate between factors affecting slaughtering houses and those affecting the further processing of meat.

\subsubsection{Slaughterhouses}

Two main factors could explain changes in the demand of energy per unit of product: (a) changes in the share of frozen products and (b) changes in the share of cut and deboned products. From an energy point of view, the increase or decrease of frozen products is important because freezing increases the electricity demand. Likewise, the trends towards cut-up and deboned products imply an increase of electricity and fuel demand. Higher electricity consumption is a consequence of the increasing use of automated equipment to cut-up and the temperature conditions in which cutting and debonning can take place, ${ }^{18}$ while increased heat consumption is a consequence of an increasing demand for hot cleaning water. Fig. 6 shows the importance of freezing, cutting and debonning by type of meat and country. ${ }^{19}$ Note that while the share of frozen products is only significant in the poultry sector, and with exception of pig meat production, the general trend is towards a decrease in the production of frozen fresh meat. On the contrary, the share of cut-up and deboned products is significant for all meat and has increased in the last decade. We estimate the influence of the shares and their change on the EEI of the meat sector as follows.

Since the $\mathrm{SEC}_{\text {ref }}$ we have used for cattle, poultry and pig meat slaughtering (Table 4) refer to fresh chilled products, not frozen ones, we correct these figures for the additional energy demand. Data from the Danish meat industry indicate that freezing would add between 120 and $260 \mathrm{kWh}$ per tonne of poultry product ${ }^{20}$ [32], $115 \mathrm{kWh} / \mathrm{t}$ of pigmeat and $80 \mathrm{kWh} / \mathrm{t}$ (cattle) [33]. Note that frozen poultry products demand more energy not only because of higher refrigeration requirements but also because the meat is submitted to higher temperatures during scalding. Frozen poultry (and poultry for frying) undergoes what is called hard-scalding,

\footnotetext{
${ }^{18}$ According to European legislation temperature of the cutting room should not exceed $10^{\circ} \mathrm{C}$.

${ }^{19}$ Information was not available for all years and countries.

${ }^{20}$ The range given depends on packaging type.
} 
Table 5

Comparison of $\mathrm{SEC}_{\mathrm{ref}}$ values (in primary energy): the effect of freezing, cutting and deboning meat

\begin{tabular}{lllll}
\hline Product & $\begin{array}{l}\mathrm{SEC}_{\text {ref }} \text {, whole and } \\
\text { chilled }(\mathrm{MJ} / \mathrm{t} \text { dress } \\
\text { carcass weight })\end{array}$ & $\begin{array}{l}\mathrm{SEC}_{\text {ref }} \text {, whole and } \\
\text { frozen }(\mathrm{MJ} / \mathrm{t} \text { dress } \\
\text { carcass weight })\end{array}$ & $\begin{array}{l}\mathrm{SEC}_{\text {ref, cut-up, }} \\
\text { deboned and chilled } \\
(\mathrm{MJ} / \mathrm{t} \text { dress carcass } \\
\text { weight })\end{array}$ & $\begin{array}{l}\text { SEC } \\
\text { deboned and frozen } \\
(\mathrm{MJ} / \mathrm{t} \text { dress carcass } \\
\text { weight })\end{array}$ \\
\hline $\begin{array}{l}\text { Beef, veal and sheep } \\
\text { Pork }\end{array}$ & 1390 & 2110 & 2146 & 2866 \\
Poultry & 2093 & 3128 & 2849 & 3884 \\
\hline
\end{tabular}

with water temperatures in the range of $58-60{ }^{\circ} \mathrm{C}$, while poultry for fresh sale is submitted to soft-scalding $\left(50-53{ }^{\circ} \mathrm{C}\right)$. Assuming 1.41 of water for the scalding tank per $\mathrm{kg}$ poultry, ${ }^{21}$ and an efficiency of $70 \%$ of the steam system (boiler and distribution lines), ${ }^{22}$ we calculate an additional fuel demand of about $83.8 \mathrm{MJ} / \mathrm{t}$.

To calculate the increase in energy demand as a consequence of cutting and debonning we used data published in a report on best available technologies for Finnish slaughterhouses which indicates that cutting up and debonning consume $60 \mathrm{kWh} / \mathrm{t}$ of finished product (electricity) and $216 \mathrm{MJ} / \mathrm{t}$ of finished product (fuel) for cattle, poultry and pigs [39]. As data is given in $\mathrm{kg}$ of finished product, we use the following carcass cutting yields to convert kilograms of boneless cut meat to dress carcass weight: 1.53 for cattle, 1.37 for pork and 1.8 for poultry. Table 5 shows the $\mathrm{SEC}_{\text {ref }}$ for products which are frozen, cut-up and deboned.

Figs. 7A and B depict the effects of correcting the EEI by including frozen products or by cut-up products for the whole meat and for the slaughtering sector. A more accurate picture is achieved if we correct for products that are cut-up, deboned and frozen. However, this demands a high level of disaggregate data that at the moment are only available for some years for the poultry sector. The effect on the trend is shown in Fig. 7C. Correcting for cutting and freezing: (a) decreases the absolute value of the indicator, (b) tends to decrease the gap between countries and, (c) can explain some of the fluctuations showed by the trends at a disaggregate level but it does not explain the increase on EEI showed by the whole meat sector.

\subsubsection{Further processing of meat-fast food}

Another possible reason for the increase in the EEI of the meat sector in Fig. 6 could be the use of more energy intensive processes in the processed meat sector (NACE 1513). The central problem we face is that not enough information is available to distinguish among different types of processed meat products and the related energy consumption, thus the EEI trends shown do not correct for changes in the production mix among further processed meat products. We therefore point out some developments that could explain the increasing energy demand per product: (a) increasing number of new products, (b) structural changes in the production from less energy intensive products towards more energy intensive ones, (c) increasing packaging and automation (which increases the amount of electricity demand), and (d) increasing food hygiene standards (see Section 6.2).

An increasing number of products could increase energy demand because if processed in small amounts, production lines would be used for different products which increases the amount of energy used during cleaning and start-ups. However, at the moment it is not possible to test this hypothesis since statistical data do not allow monitoring the entrance and amount of new products. The only information we found comes from a report from the Dutch Ministry of Economic Affairs recognizing that "new products were introduced (in the meat sector), leading to extra process stages (including frying) and to higher energy consumption" [42].

\footnotetext{
${ }^{21}$ This value is an average figure. It has been calculated based on data provided by Pontoppidan and Hansen [32], Derden et al. [40], Environmental Agency, Integrated Pollution and Control [41].

${ }^{22}$ Although for some food industries boiler efficiencies of $80-90 \%$ are common, we have considered that boilers in slaughterhouses are older and the level of maintenance is not the same as in other industries, hence a $70 \%$ efficiency was considered appropriate.
} 


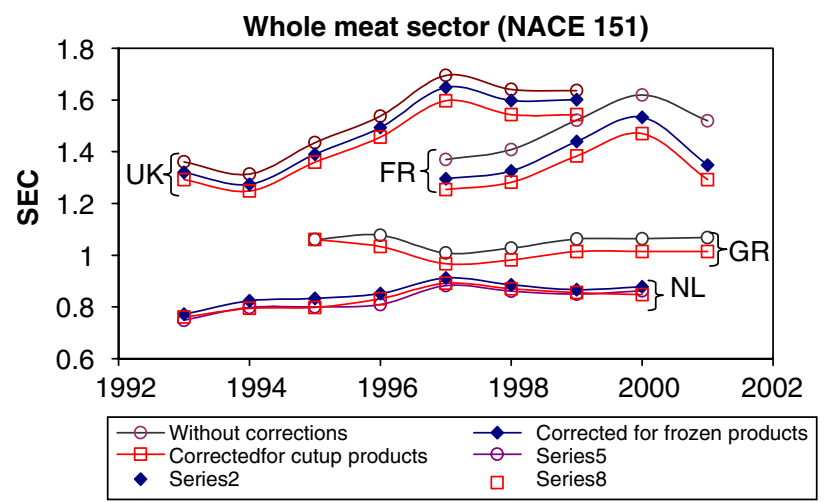

(A)

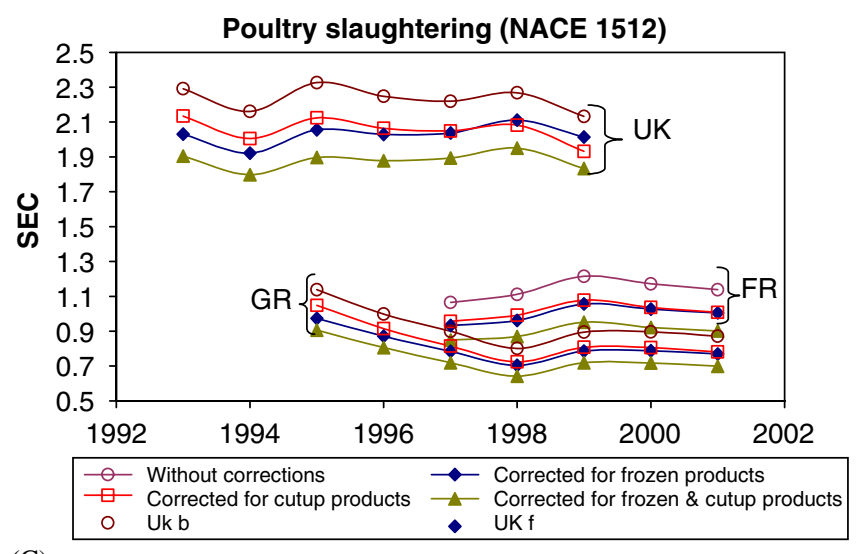

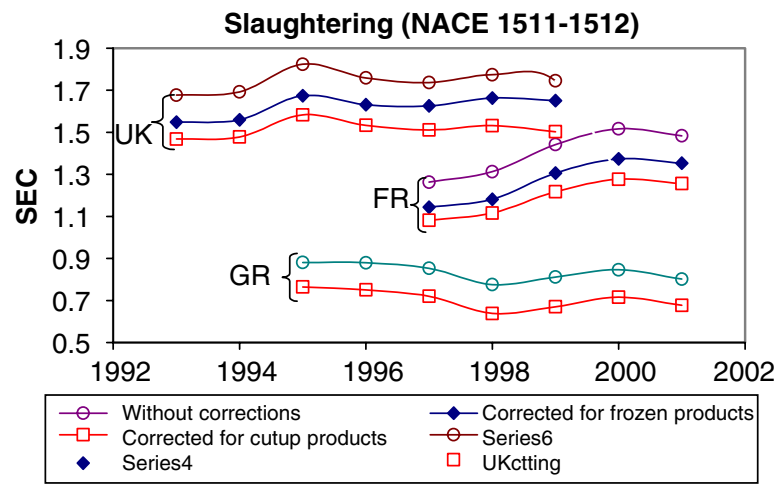

(B)

FR: France

GR: Germany UK: United Kingdom

Fig. 7. Influence of different corrections in the specific energy consumption of the meat sector at different levels of aggregation.

Furthermore, the Dutch Long-Term Agreements ${ }^{23}$ for the meat sector stated that in the year 2000 about $8 \%$ of the total energy used by the companies that signed the covenant was due to the introduction of new products [43].

As an attempt to obtain better insights into the contribution of new products to overall energy use, Fig. 8 compares the increasing energy demand in France with production trends. According to Fig. 8A prepared dishes and conserves may have contributed decisively to the increased primary energy demand in the last 5 years. Fig. 8B provides some support for this hypothesis since (a) increasing packaging is accompanied by the increasing demand of energy of the sector, and (b) the role of frozen products is quite limited. However, due to lack of data, a detailed analysis that allows calculating the effect of the different categories on the increasing energy demand is not possible.

\subsection{Increasing demand for food security}

A different impact on energy consumption does not come from changes in production mix but from changes in process conditions. During the last decade, the food scandals which have shaken the sector have generated a strong focus on food safety. As a reaction to public concern, stringent hygiene requirements in meat companies (and pressure to accomplish such requirements) have been established. Temperature has been a fundamental factor in increasing food safety (cold and hot treatments are effective ways of controlling microbiological growth and eliminating pathogens). A report made for the Dutch meat sector in the context of

\footnotetext{
${ }^{23}$ The LTAs are voluntary agreements between a specific sector and the minister of economic affairs. It involves a commitment by a sector to make efforts to improve energy efficiency by a percentage in a pre-arrange term. LTAs are based on physical measures of output.
} 


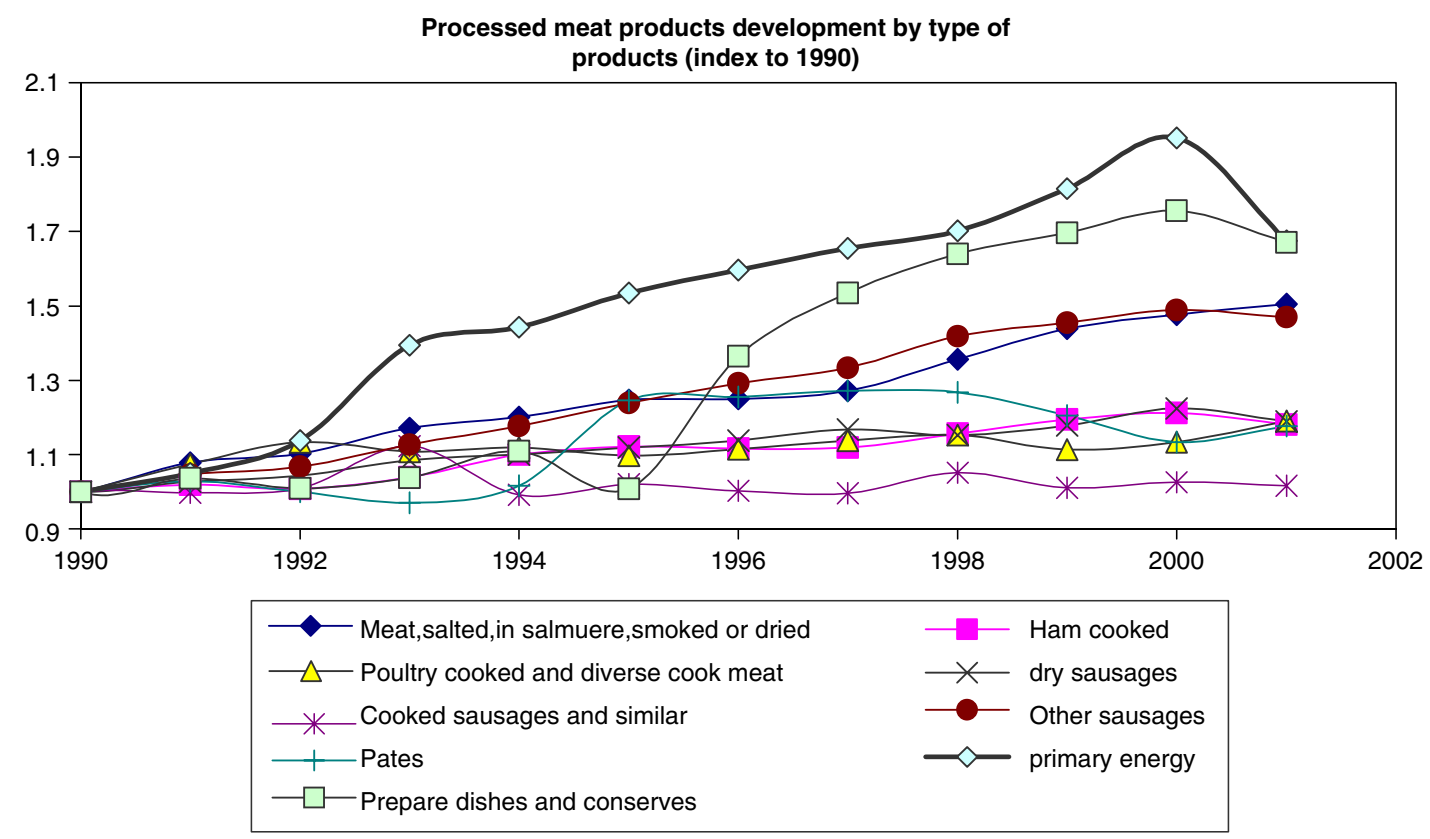

(A)

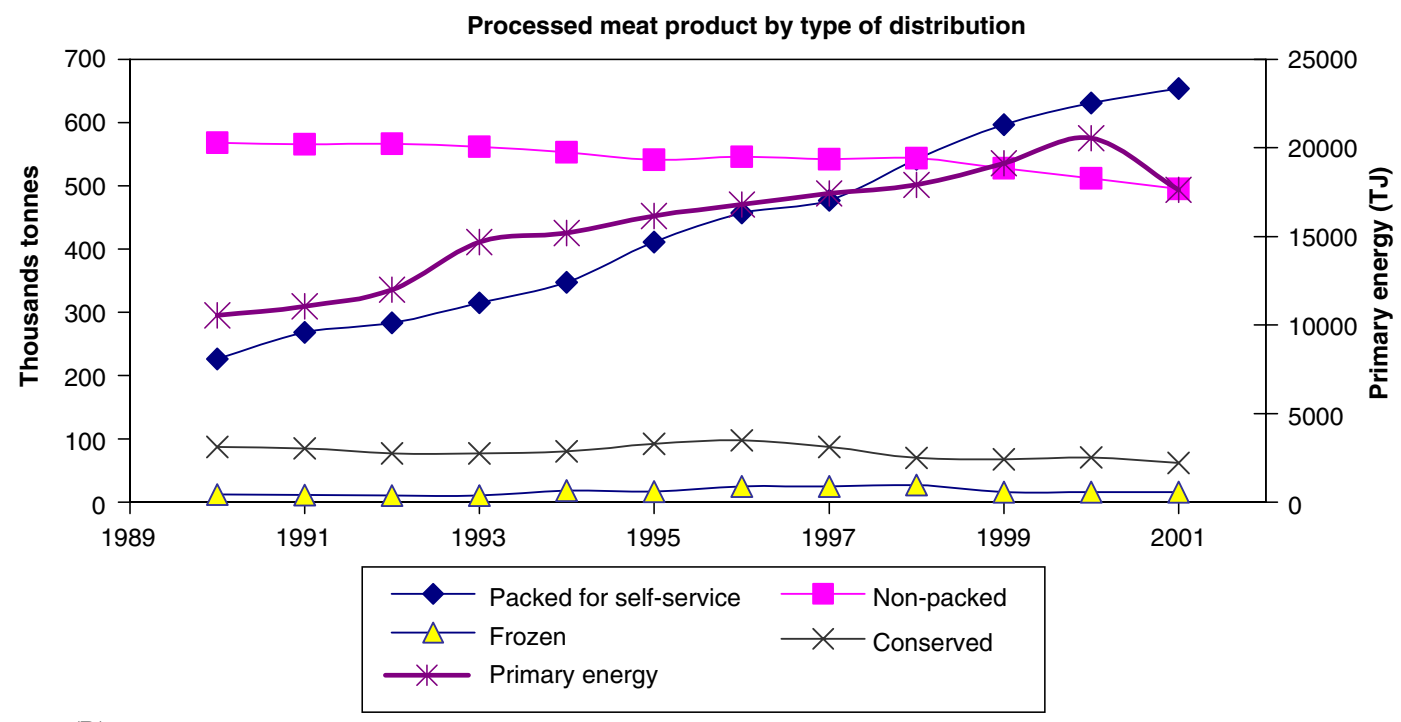

(B)

Fig. 8. Comparison by type of product and primary energy use for the French further processed meat sector.

the long-term agreements (LTA) pointed out that "the introduction of the Hazard Analysis Critical Control Points method for food health, safety and quality led to an increase in energy consumption which eliminated the effect of conservation measures" [42]. Part of the increased amount of gas use originates from the higher demand for hot water which is related to the more stringent hygiene requirements (e.g., hot water is used for the sterilization of tools and bacterial decontamination of carcasses). Furthermore, and as noted before, refrigeration is the biggest consumer of electricity. In fact, some studies have already shown that EC slaughterhouses complying with EC temperature legislation use more electricity than those that do not [16]. 
Table 6

Scenarios used to estimate the influence of increased electricity use as a consequence of more stringent EC hygiene regulations

\begin{tabular}{lll}
\hline Scenario & \multicolumn{2}{l}{ Share of the electricity that has been used to accomplish with EC regulations (\%) } \\
\cline { 2 - 3 } & Slaughterhouses & Meat processing facilities \\
\hline 1 & 10 & 10 \\
2 & 25 & 10 \\
3 & 25 & 25 \\
\hline
\end{tabular}

We have made an estimate for the increased fuel demand as a consequence of implementing EU legislation. Since there is not enough data to establish at which penetration rate EU slaughterhouses are implementing EU legislation ${ }^{24,25}$, we have assumed the following:

- In the year 1990 , slaughterhouses were using water for cleaning and sterilization at $60^{\circ} \mathrm{C}$ and in the year 2001 the temperature is $82^{\circ} \mathrm{C}$.

- In the year 1990, poultry slaughterhouses were not using hot pre-wash before evisceration, while this was the case for the year 2001.

- In the year 1990, slaughterhouses did not chill the blood recollected and in the year 2001 all blood was chilled to $5{ }^{\circ} \mathrm{C}$.

The result of implementing these three measures leads to an increase in energy demand of about $335 \mathrm{TJ}$ in France, $316 \mathrm{TJ}$ in Germany, $142 \mathrm{TJ}$ in the Netherlands and $369 \mathrm{TJ}$ in the United Kingdom. Because there is not enough information to calculate the additional demands on electricity for cooling as a consequence of stringent food security in a bottom-up way, we have proceeded as follows. Since Germany, France and the United Kingdom publish detailed energy figures for slaughtering houses and meat processing factories and the shares of electricity used for cooling are known (Table 3), we conduct a sensitivity analysis using assumptions for the share of additional electricity used to comply with EC regulations (Table 6). The results shown in Fig. 9 depict what would have been the EEI of the meat sector in the year 2001 if the regulations had not been implemented. The influence of increasing electricity use in the EEI is higher than the influence of increasing fuel demand. Increased use of electricity could explain between $3 \%$ and $8 \%$ of the increase in the value of the EEI of the meat sector in the United Kingdom, 3\% and 9\% in France, and 2\% and 4\% in Germany in the period 1990-2001.

Another consequence of the implementation of the new EU measures has been felt in the rendering sector. In the late 1980s the trend in the rendering industry was to move from a batch process towards a continuous process [47]. The continuous process is considered a more reliable process, which generates less water and air pollution, involves less manual work and no organic solvents. Furthermore, it consumes around 30-40\% less heat per tonne of product than the batch process $[48,49] \cdot{ }^{26}$ However, as a consequence of Council Directives $90 / 667^{27}$ and $96 / 449^{28}$ processing conditions have changed. In the United Kingdom, for instance, specified bovine material $(\mathrm{SBM})^{29}$ has to be rendered in separated plants or dedicated lines within the plants, generally

\footnotetext{
${ }^{24} \mathrm{We}$ found partial information for EC approved slaughterhouses in the United Kingdom. The report states that in 1992 only $12 \%$ of slaughterhouses were approved while the number in 1996 increased to 62\% [44]. These figures support our assumptions.

${ }^{25}$ The values were calculated assuming that water use at $82^{\circ} \mathrm{C}$ is about 301 per pig, 1051 per cattle, 4.31 per chicken [32-33]; the amount of water use for hot washing before chilling in poultry, according to EU legislation, is 1.5-3.51 per carcass [45]; average amount of blood that can be collected per animal is $3.6 \mathrm{~kg}$ per pig, $13.6 \mathrm{~kg}$ per cattle, $2.5 \mathrm{~kg}$ per lamb and $0.06 \mathrm{~kg}$ per chicken [46] and requirements for blood refrigeration is $30.5 \mathrm{kWh} / \mathrm{t}$ of blood [16].

${ }^{26}$ The reason for this is that in the continuous process there is reutilization of heat.

${ }^{27}$ It establishes that high risk material must be heated to a core temperature of at least $133{ }^{\circ} \mathrm{C}$ for 20 min at a pressure of 3 bar.

${ }^{28}$ It establishes the approval of alternative heat treatment systems for processing animal waste [45].

${ }^{29}$ Specified meat offal comprises the skull, including the brain and the eyes, tonsils, intestines, thymus and spinal cord of bovine, ovine and caprine animals.
} 


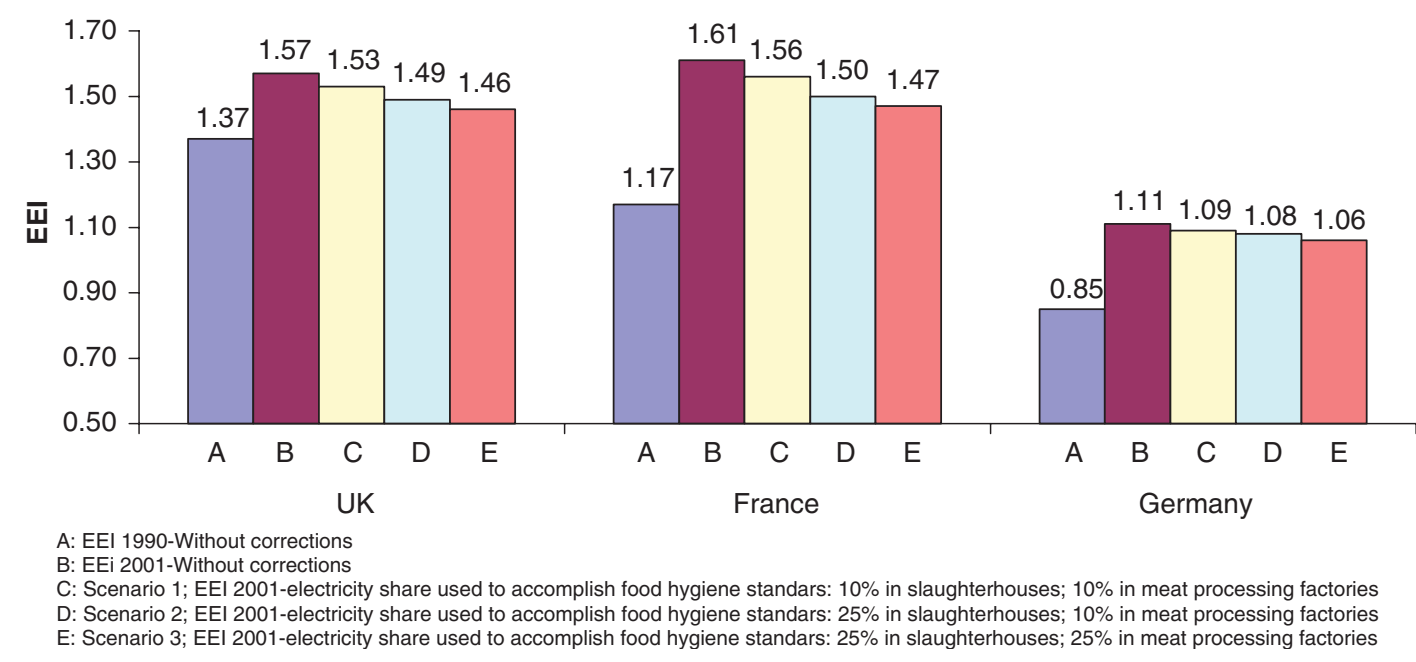

Fig. 9. Influence on increased energy demand as a consequence of hygiene regulations in the EEI of the meat sector.

in batch units; the same development has occurred in France [47]. In the Netherlands, the introduction of the new legislation and the opinion of the steering committee of the $\mathrm{EC}^{30}$ caused a reintroduction of batch sterilization in all Dutch rendering plants in 1996. Hence, the EC directives have contributed to an increasing energy demand in the rendering industry (with exception of Germany, where the Directive 90/667/EEC is essentially German law and has been applied by rendering houses since the beginning of the 1980s [50]). To estimate this increase we assume that in the year 2001, SBM, ${ }^{31}$ meat-and-bone meal for animal feed and fallen stock was pressure treated in batch vats. The specific energy consumption of such a process is reported to be $1960 \mathrm{MJ}$ of primary energy/tonne raw material [38]. Under these assumptions, we calculated, for the year 2001, an increase of about 476, 308 and 362 TJ in the energy demand of the rendering process for France, the United Kingdom and the Netherlands, respectively.

In conclusion, stringent hygiene regulations can explain a significant share of the increasing EEI. For instance, in the United Kingdom, and depending on the impact on the electricity demand, it can explain between $42 \%$ and $78 \%$ of the $32 \%$ increase shown by the EEI between 1990 and 2001 . While in France, it explains between $18 \%$ and $37 \%$ and in Germany between $14 \%$ and $32 \%$. Because of the aggregate nature of the Dutch data we could not estimate the influence of hygiene in electricity demand; however, if the effect was $3 \%$ (minimum of French and United Kingdom and average Germany), hygiene regulations could explain already one-third of the $35 \%$ increase in the EEI shown by the Dutch meat sector.

\section{Conclusions}

The purpose of this paper has been to analyse energy use and energy efficiency developments for the meat industry of four European countries in the last decade. Our results show that during the last decade there has been an increase in both energy demand and specific energy consumption in the meat industry of the four countries analysed (between 14\% and 32\%). In exploring the causes for such trends we found that strong hygiene regulations can explain up to two-thirds of the decrease on EEI and that the role of increasing shares on freezing and cutting fresh meat is quite limited in all countries. There is, however, a significant share of the increase in the energy efficiency indicator (EEI) that could not be explained. A possible cause is an increase on

\footnotetext{
${ }^{30}$ When the batch system was changed to continuous it was overlooked that the heat treatment in some of the systems were less than in conventional batch systems. Continuous systems are indeed able to get rid of salmonella and vesicular disease, however their effectiveness to eliminate BSE is doubted.

${ }^{31}$ In the United Kingdom, SBM is calculated to be $46.5 \mathrm{~kg}$ per cattle and $2 \mathrm{~kg}$ per sheep and goats, while for France and the Netherlands it is $17 \mathrm{~kg}$ per cattle and $2 \mathrm{~kg}$ per sheep and goats [36]. The higher amount per cattle in the United Kingdom reflects the fact that British law (Specified risk material order 1997) considers as SBM the head and spleen of the animals.
} 
energy intensive process in the further processed meat sector; however, further analysis was halted by the lack of current available data. Understandably, when looking at the meat sector, studies on processes and hygiene have focused their attention on slaughterhouses; not only are they considered an important source of epidemics but also have a limited number of processes. On the other hand, only very little attention has been paid to the further processed meat sector, with more than 40 different product categories. Despite a couple of studies which deal with sausage-making there is no information available on SEC by products which imply that changes in structure within the further processed meat sector remain in the EEI.

This paper thus shows that, from a methodological point of view, it is viable to develop EEIs using available statistical data in a heterogeneous non-energy intensive sector. However, we found that data availability is indeed a constraint when exploring the drivers behind changes in energy efficiency. Hence, understanding the drivers increase data on energy consumption by process and product is necessary and this can only be achieved in active cooperation with the industry. Gathering such data will certainly come at a cost, but the research towards this direction is both promising and challenging.

\section{Acknowledgements}

We wish to thank the following people for their help on data collection and comments on early drafts of this paper: Ernst Worrell (Berkeley Laboratory, USA), Fons Pennartz (KWA, the Netherlands) and Henk Hupkes (Meyn Food Processing Technology).

\section{References}

[1] Metz B, Davidson O, Swart R, Pan J, editors. Climate change 2001: mitigation. Contribution of working group III to the third assessment report of the intergovernmental panel on climate change (IPCC). Cambridge and New York: Cambridge University Press; 2001.

[2] Freeman S, Niefer M, Roop J. Measuring industrial energy efficiency: practical issues and problems. Energy Policy 1997;25(7-9):703-14.

[3] Price L, Michaelis L, Worrell E, Khrushch M. Sectoral trends of global energy use and greenhouse gas emissions. Mitigation and adaptation strategies for global change, vol. 3, 1998. p. 263-319.

[4] Farla J. Physical indicators of energy efficiency. PhD thesis, Faculty of chemistry, Utrecht: Utrecht University, Department of Science, Technology and Society, Copernicus Institute; 2000.

[5] Hyman B, Reed T. Energy intensity of manufacturing processes. Energy 1995;20(7):593-606.

[6] Nanduri M, Nyboer J, Jaccard M. Aggregating physical intensity indicators: results of applying the composite indicator approach to the Canadian industrial sector. Energy Policy 2002;30:151-63.

[7] Phylipsen GJM, Blok K, Worrell E. Handbook on international comparisons of energy efficiency in the manufacturing industry. Utrecht: Utrecht University, Department of Science, Technology and Society, Copernicus Institute; 1998.

[8] Commission of the European Communities. Proposal for a directive of the European Parliament and of the Council on energy enduse efficiency and energy services (presented by the Commission). COM 2003, 739 final report, Brussels: CEC; 2003.

[9] Centraal Bureau voor de Statistiek. Energy-supply in the Netherlands, annual figures, part 2 (de nederlandse energiehuishouding, jaarcijfers, deel 2). Voorburg: CBS; Various years [in Dutch].

[10] Agreste. The consumption of energy in the agro-industry (les consummations d'énergie dans les IAA). Ministère de l'Agriculture et de la Pêche, Paris: Scees; Various years [in French].

[11] Department of Trade and Industry (DTI). Energy consumption in the United Kingdom. United Kingdom: DTI; 2001 See also: http:// www.dti.gov.uk/energy/.

[12] Statistisches Bundesamt. Production data. Serie 4.1.1. Energy consumption and energy supply of the entities of the processing sector as well as mining and non-metallic minerals (Produzierendes Gewerbe. Reihe 4.1.1. Beschäftigung, Umsatz und Energieversorgung der Unternehmen und Betriebe des Verarbeitenden Gewerbe sowie des Bergbaus und der Gewinnung von Steinen und Erden). Stuttgart: Statistisches Bundesamt; various years [in German].

[13] Intergovernmental Panel on Climate Change. Good practice guidance and uncertainty management in national greenhouse inventories. Japan: Institute of Global Environmental Strategies; 2002.

[14] International Energy Agency (IEA). $\mathrm{CO}_{2}$ emissions from fuel combustion 1971-2000. Paris: IEA-OECD; 2002.

[15] Brook K. Temperature correction procedures to monitor changes over time of energy consumption data. United Kingdom: DTI; 2001 See also: http://www.dti.gov.uk/energy/inform/energy_trends/tempmethod1.htm.

[16] European Commission. Integrated pollution prevention and control. Draft reference document on best available technologies in the slaughterhouses and animal by-products industries. Final draft. Brussels: EC; 2003 See also: http://eippcb.jrc.es/pages/ BActivities.cfm.

[17] Infomil. Meat industry (vleesindustrie). Informatieblad. De Haag: Infomil; 1996 [in Dutch]. 
[18] Food and Agricultural Organization of the United Nations. FAOSTAT data- Agriculture. FAO, 2004. See also: http://www.fao.org/ waicent/portal/statistics_en.asp.

[19] United Nations. Industry commodity production statistics database 1950-2000. CD Rom prepared by Industry and Energy Section, Statistics Division, Department of Economic and Social Affairs, United Nations Secretariat, 2002.

[20] Becker T, Benner E, Glitsch K. Summary report on consumer behavior towards meat in Germany, Ireland, Italy, Spain, Sweden and the United Kingdom - results of a consumer survey. Report submitted to the Commission of the European Union in January 1998, Göttingen, Selbstverlag, 1998.

[21] European Union. Prospects for agricultural markets in the European Union 2001-2008. Brussels: EC; 2001 See also: http:// europa.eu.int/comm/agriculture/publi/caprep/prospect2001/fullrep.pdf.

[22] European Commission (EC). Panorama of EU industry, vol. 1. Brussels, Luxemburg: EC; 1997.

[23] Langezaal C, Grolman M. Livestock. Annual report for the Netherlands. Report code 52, Washington DC: USDA; 1995.

[24] BSE enquire. The BSE enquire report. The enquire into BSE and variant CJD in the United Kingdom, United Kingdom, 2000. See also: http://www.bseinquire.gov.uk.

[25] European Commission (EC). The welfare of chickens kept for meat production. Report of the scientific committee on animal health and animal welfare. Report Sancob 3/ah/r15/2000, Brussels: EC; 2000.

[26] Alcamo J. IMAGE 2.0: integrated modeling of global climate change. Dordrecht: Kluwer Academic Publishers; 1994.

[27] Northen J, Henson S, Burns J. National Quality Report: The United Kingdom. Report for the Project "Quality policy and consumer behavior”. FAIR-CT-95-0046, Germany: University of Hohenheim, Institute for Agricultural Policy and Agricultural Markets; 1997.

[28] Organization for Economic Cooperation and Development (OECD). Costs and benefits of food safety regulations: Fresh meat hygiene standards in the United Kingdom. Working paper No. 99, Paris: OECD; 1997.

[29] International Energy Agency (IEA). Energy policies of IEA countries. France 2000 review. Paris: IEA-OECD; 2000.

[30] Bossebeouf D. Personal communication. Agence de l'environnement et de la maitrise de l'energie, 27 April 2003.

[31] Farla J, Blok K. The use of physical indicators for monitoring of energy intensity developments in the Netherlands $1980-1995$. Energy 2000;25(7):609-38.

[32] Pontoppidan O, Hansen P. Implementation of cleaner technology in the poultry abattoir branch. Project report (udbredelse af renere teknologi på fjerkræslagterierne. Projektrapport). Environmental Project No. 573, Danish EPA, 2000 [in Danish]. See also: http:// www.mst.dk/udgiv/publikationer/2000/87-7944-306-0/html/.

[33] Pontoppidan O, Hansen P. 2001. Cleaner technology in the poultry and cattle slaughtering branch. Project report (renere teknologi på svine-og kreaturslagterier Resume-rapport). Environmental report No. 9, Danish EPA, 2001 [in Danish]. See also: http:// www.mst.dk/udgiv/publikationer/2000/87-7944-306-0/html/.

[34] Suijkerbuijk M, van Oosterhout C, Hoogenkamp A. Slaughthering and the meat industry (slachterijen en vleeswaren industrie). Samenwerkingproject Processbeschrijving Industrie Nederland (SPIN). Report 773006173. Bilthoven: RIVM; 1995 [in Dutch].

[35] Meat and Livestock Commission (MLC). A study of the competitive position of the read meat industry in Great Britain in relation to the collection, processing and disposal of animal by-products both in Great Britain and other EU Member States. London: MLC Planning and Forecasting Group; 1998.

[36] Meat and Livestock Commission (MLC). Economic overview of the United Kingdom beef industry. London: MLC Planning and Forecasting Group; 1998.

[37] Nielsen L. Personal communication. Daka, 20 April 2004.

[38] Schreurs M. Personal communication. Rendac, 29 April 2004.

[39] Finish Environmental Institute (FEI). Finish report on best available techniques in slaughterhouses and installations for the disposal or recycling of animal carcasses and animal waste. Report 539. Helsinki: FEI; 2000.

[40] Derden A, Scrijver J, Suijekerbuijk M, van de Meulebroecke A, Vercaemst P, Dijkmans R. Best available technologies for the slaughthering sector (beste beschokbare technieken voor de slachthuisector). Final report 2003/IMS/R/029. Mol: Vito; 2003 [in Dutch].

[41] Environmental Agency. Integrated pollution and control (IPPC). Guidance for the poultry processing sector. Environmental Agency, sector guidance note IPPC.S6.11. United Kingdom, 2001.

[42] Ministry of Economic Affairs. Long-term agreements on energy efficiency. Progress in 1998. The Hague: MINEZ; 1999.

[43] NOVEM. Final report. Development of energy efficiency in the meat industry. Novem, report 2013454/304/SD/NW/156312. Utrecht: Novem; 2001.

[44] Shaoul J. BSE: for services rendered? The drive for profits in the meat industry. Department of Accounting and Finance. United Kingdom: University of Manchester; 1996.

[45] European Commission. Commission decision 96/449/EC of 18 July 1996. Official Journal of the European Communities 1996;L184:43.

[46] Gracey JF. Meat plant operations. United Kingdom: Chalcombe Publications; 1998.

[47] Coopers \& Lybrands. The United Kingdom beef industry. Report on the rendering sector. London: Coopers \& Lybrands; 1996.

[48] Krenk P. An overview of rendering structure and procedures in the European Community. In: Bradley R, Savey M, Marchant B, editors. Sub-acute spongiform encephalopathies. Brussels and Luxemburg: ECSC, EEC, EAEC; 1991. p. 161-7.

[49] Prosper De mulder Ltda, Croda International plc. A report on the merger situation. Presented to Parliament by the Secretary of State for Trade and Industry. Cm 1611. London: Monopolies and Merger Commission; 1991.

[50] Fodgen M. By-product of animal origin and animal waste. 1991 investigation into EC collection and rendering practices. United Kingdom: Meat and Livestock Commission; 1991. 